\title{
Multifactor Productivity of Smallholder Yam Farmers in Ebonyi State, Nigeria
}

\author{
Kadurumba CHUKWUEMEKA ${ }^{{ }^{*}}$, Njoku Ignatius ANAYO ${ }^{2}$, Achi OGECHI ${ }^{1}$ \\ ${ }^{1}$ Department of Agricultural Extension Management, Federal College of Agriculture Ishiagu, P.M.B 7008, Ebonyi State, Nigeria \\ ${ }^{2}$ Department of Marketing, Federal College of Agriculture Ishiagu, P.M.B 7008, Ebonyi State, Nigeria
}

\begin{abstract}
The study analysed the multifactor productivity among smallholder yam farmers in Ebonyi South, Ebonyi North and Ebonyi Central Agricultural zones of the State. The specific objectives were to determine the socio-economic characteristics of the yam farmers in the study area, to analyse the multifactor productivity and scale of production among smallholder yam farmers, to determine the factors affecting multifactor productivity among smallholder yam farmers and identify constraints of increased yam production in the study area. Two-stage random sampling technique was used to select one hundred and twenty (120) yam farmers from areas of intense yam cultivation in the three zones. Cobb-Douglas production function was used to analyse individual factor productivity and scale of production in yam enterprise. The results revealed that coefficient of farm size, hired labour, household size and planting materials, would reduce multifactor productivity of yam farms by $8.6 \%, 1.05 \%, 2.2 \%$ and $0.45 \%$, respectively. The results also showed that $10 \%$ increase in age, income, credit access and experience would increase multifactor productivity of yam farms by $0.071 \%, 0.133 \%, 0.543 \%$ and $0.139 \%$, respectively. The $\mathrm{R}^{2}$ values of 0.864 implies that about $86 \%$ of variations in multifactor productivity in yam enterprises are explained by the explanatory variables in the model. The problems identified include inadequate land, finance, high transportation cost, hired labour, pests and diseases, bad infrastructure, network, inadequate storage facilities, etc. The results of the study expressed the need of active policies aimed at intensifying extension services, encouraging farm mechanization and provision of credits at subsidized rate in the state.
\end{abstract}

Key words: yam, Dioscorea spp., multifactor productivity, smallholder, determinants, resources

\section{INTRODUCTION}

Agriculture is the dominant activity in rural areas of Nigeria (Onyeabor and Alimba, 2006). According to National Institute of Socio-economic Survey (NISER, 2002), there are about 4 million farm units, mostly small scale farmers all contributing about $40 \%$ of gross domestic product (GDP) and providing employment directly or indirectly to over $71 \%$ of Nigerians. In most developing countries including Nigeria, agriculture is the key to sustain growth to the modern economy. Yam, botanically known as Dioscorea spp., represents a group of monocotyledonous annual tuber producing crops commonly grown in Nigeria as well as in many other tropical countries. The genus Dioscorea comprises of over 600 species with only 10 species producing edible tubers. Six of them are cultivated in Africa: $D$. rotundata (white yam), D. alata (water yam), D. cayenensis (yellow yam), D. bulbifera (aerial yam), D. esculanta (Chinese yam), D. dumentorum (threeleaved yam). Among these six species, the following three are commonly planted in the study area: white, yellow, and water yam (Amusa, 2000).

According to FAO (2013), Nigeria accounts for over 65\% of the world yam production valued at $\$ 7.75$ billion and cultivated on about 2.9 million hectares of the land in 2015 . 
In Ebonyi State Nigeria, smallholder yam famers are characterized by low productivity (Pius and Odwrwuedemie, 2006). The problem of declining crop productivity in Nigeria is significant. Despite all human and material efforts devoted to agriculture, the productivity of most yam crop farmers are still low (Izekor and Olumese, 2010). Some of the constraints to yam production in the study area are unavailability of planting materials, soil degradation, poor handling and storability, pest and disease and other environmental factors (Ibitoye and Attah, 2012). Seed yam for cultivation has continued to be a problem for the farmers. The cost of producing yam is also observed to be higher compared with other tubers in the country. This is largely due to high cost of seed yam. On the average, about $28 \%$ of the annual yam harvest is used as seed yam (Kushwaha and Polycarp, 2001). This situation has caused yam cultivation to suffer a severe setback and reduced its productivity due to high cost of production. The role of productivity in accelerating the pace of economic growth is well recognized in literature on growth. The neoclassical accounting frame work perceived the growth of output as the sum total of the growth of capital accumulation, growth of labour and the growth of productivity or efficiency (Akinlo, 2006). The recent productivity slowdown in the economic realities of most nations has increasingly attracted the attention of the analysis and policy makers. Previous estimates such as those based on OECD productivity data base have in fact remarked a decreasing productivity pattern with negative rates for multifactor productivity also known as total factors productivity in some countries (Milana et al., 2008).

Improvements in agricultural productivity are a fundamental precondition for economic development. It is only when the agricultural productivity is very high that a farm family can feed many rural and urban residents which represent the total population. In more general terms, when agricultural productivity is high, factors of production which include land, labour, capital and other resources can be released from food and fibre production to expand nonagricultural sector of the economy (Akpan et al., 2011).

As the name implies, total productivity known as overall productivity in the agricultural sector can be determined by evaluating the measures of labour, capital and other factors productivity. Today, multifactor productivity is derived to take into effect all the inputs of production. Productivity measurement provides tools to assess the efficiency and effectiveness of the sector in similar manner as they do for individual firms. The level of productivity in Nigeria has remained low and the evidence lies in every sector including agriculture which provides basis for the existence of agribusiness. However, sustained yam production in the state could be achieved under increasing agricultural resources intensification and dynamic economic environment only if resource utilization occurs in the rational stage of classical production surface. Considering the importance of root crop sector for the economy of Ebonyi state (job creation, self-food sufficiency, and food complement resource), the production constraints inherent in yam production and various agricultural programmes as well as polices implemented in the state to boast root crops production, it has become imperative to empirically analyse determinants of multifactor productivity among yam farmers in the state. The indices of farm resource productivity will further guide policy makers in formulating sustainable policy frame work for improvement of welfare of yam farmers which will lead to increase in productivity and multifactor productivity among yam farmers in the state. Therefore, the study specifically analysed farm resource productivity and multifactor productivity as well as factors influencing multifactor productivity among yam farmers in the state.

\section{MATERIALS AND METHODS}

\section{The study area; data sources and data collection procedures}

The study was conducted in Ebonyi State Nigeria. The state is located in south-eastern Nigeria. Ebonyi State lies between latitude $5^{\circ} 10^{\prime \prime}$ and $6^{0} 35^{\prime \prime}$ North of the equator and longitudes $7^{0} 10^{\prime \prime E}$ and $8^{0} 5^{\prime \prime E}$ the Greenwich Meridian. Ebonyi State has 1.7 million inhabitants in a total area of $5,530 \mathrm{~km}^{2}$ (NPC, 2006). The state is bordered on the north by the state of Benue, on the west by the state of Enugu, on the south by the state of Abia and on the east by the state of Cross River.

The state is in the rainforest area with trees and animals of different species. Annual precipitation is high, ranging from $1200 \mathrm{~mm}$ to $1600 \mathrm{~mm}$ and a temperature range of 27.0 to $33.0^{\circ} \mathrm{C}$ (EBSMARD,1996). The state is sub-grouped into three areas for administrative and agricultural purposes. These are Ebonyi North, Ebonyi South and Ebonyi Central. A two-stage random sampling technique was used to select 120 yam farmers in the intensive growing areas in the respective areas. Primary data collected includes socio-economic and production data. Personal interviews were also conducted to validate the consistency and accuracy of the information provided by respondents.

\section{Analytical techniques}

Cobb-Douglas production function was used in the study because it can handle several entries in its general form and does not introduce any distortion of its own in the face of market imperfections. The uncompressed Cobb-Douglas function further increases its potential for managing different scales of production. Various econometric estimation problems, such as serial correlation, heteroscidasticity and multi-colinearity can be adequately and simply handled. It equally facilitates calculations and has the properties of explicit ability to represent uniformity, parsimony and flexibility. Even the problem of simultaneity can be overcome.

The Cobb-Douglas production function was used to analyse productivity of individual factors and the scale of production in the yam business. Therefore, the explicit production function of Cobb Douglas has been described as follows:

$\mathrm{Yi}=\mathrm{A} \mathrm{X}_{1} \beta_{1} \mathrm{X}_{2} \beta_{2}$

where $\beta_{1}$ and $\beta_{2}$ are coefficients of factor or elasticity, $\beta_{1}+$ $\beta_{2}=1$ simply means a constant return of scale; $\beta_{1}+\beta_{2}>1$ 
implies increasing returns to scale; $\beta_{1}+\beta_{2}<1$ indicates a descending scale return. $\mathrm{Y}$ is a measure of output, while $\mathrm{X}_{1}$ and $\mathrm{X}_{2}$ represent production inputs. " $\mathrm{A}$ " is called average multifactor productivity because it simultaneously increases the marginal product of all factors (McCloskey, 1972). The production function of Cobb Douglas for each growing company has been specified as follows:

$\log Y_{1}=0+\beta_{1} \log \mathrm{SED}+\beta_{2} \log \mathrm{HiL}+\beta_{3} \log \mathrm{FAL}+\beta_{4} \log$ IR $+\beta_{5} \log$ MAN $+\beta_{6} \log \operatorname{LAS}+\beta_{7} \log \mathrm{DEP}+\beta_{8} \log$ WAT $+\mathrm{U} 1$

where:

$\mathrm{Yi}=$ Amount of yam produced by I-th Famer $(\mathrm{kg})$,

SED = Quantity of seed or planting material $(\mathrm{kg})$,

HIL $=$ Hired labour (measured in days),

ALF $=$ Family work (measured in number of days),

FER $=$ Fertilizer $(\mathrm{kg})$,

MAN = Manure $(\mathrm{kg})$,

LAS = Size of the farm (ha),

$\mathrm{DEP}=$ Depreciation of fixed assets $(\mathrm{N} / \mathrm{kg})$,

$\beta_{1}=$ Elasticity of yam production with respect to various inputs,

$\mathrm{U}=$ Error term.

After Key and McBride (2003), Bamidele et al; (2008) and Ukoha et al. (2010), the multifactor productivity of an individual farm can be measured as the inverse of the unit is the ratio of production to variable total cost as shown in Equation 3,

$T F P=\frac{Y}{T V C}=\frac{Y}{E P_{1} X_{1}}$

\section{But since}

$$
A V C=\frac{T V C}{Y} \text {, then } M F P=\frac{Y}{A V C}=\frac{1}{A V C}
$$

where TFP $=$ total factor productivity,

$\mathrm{MFP}=$ multifactor productivity,

$\mathrm{Y}=$ output quantity $(\mathrm{kg})$,

TVC $=$ total variable cost $(\mathrm{N})$,

$\mathrm{P} 1=$ unit price of the variable input,

$\mathrm{X}=$ variable input quantity.

This methodology ignores the role of total fixed costs as it does not affect the conditions for maximizing profits and efficiency of resource use. In addition, it is fixed and as such constant. To determine the factors that affect multifactor productivity among yam producers in Ebonyi State, the ordinary least squares regression method was applied to various econometric specifications, namely the functional form of Cobb-Douglas for each growing company.

$\mathrm{TFP}=\mathrm{Q}_{0}+\mathrm{Q}_{1} \mathrm{LAS}+\mathrm{Q}_{2} \mathrm{HIL}+\mathrm{Q}_{3} \mathrm{AGE}+\mathrm{Q}_{4} \mathrm{HHS}+\mathrm{Q}_{5} \mathrm{EDU}$ $+\mathrm{Q}_{6} \mathrm{INV}+\mathrm{Q}_{7} \mathrm{EXT}+\mathrm{Q}_{8} \mathrm{CRE}+\mathrm{Q}_{9} \mathrm{EXP}+\mathrm{Q}_{10} \mathrm{FER}+\mathrm{Q}_{11}$ $\mathrm{DEP}+\mathrm{Q}_{12} \mathrm{SED}+\mathrm{U}_{1}$

where:

TFP $=$ Total factor productivity of individual farm,
LAS $=$ Farm size $($ ha $)$,

$\mathrm{HIL}=$ Hired labour (measured in mandays),

$\mathrm{AGE}=$ Age of the farmers (years),

HHS $=$ Farmer's household size (number),

$\mathrm{EDU}=$ Educational attainment (years),

$\mathrm{INV}=$ Income earned from yam enterprise $(\mathrm{N})$,

$\mathrm{EXT}=$ Number of extension visits (number),

$\mathrm{CRE}=$ Credit access $(\mathrm{I}=$ access, $\mathrm{O}=$ no access $)$,

$\mathrm{EXP}=$ Farmer's experience (years),

FER $=$ Fertilizer use $(\mathrm{kg})$,

DEP = Depreciation cost of fixed capital (proxy of capital utilization $(\mathrm{N})$,

$\mathrm{SED}=$ Quantity of seed or planting material $(\mathrm{kg})$,

$\mathrm{U}=$ Stochastic error term.

\section{RESULTS AND DISCUSSION}

Table 1 presents estimates of the Cobb-Douglas production function for yam producers in Ebonyi State, Nigeria. The results of the diagnostic test show $\mathrm{R}^{2}$ values of 0.938 productions. This means that about $93.80 \%$ of the variations in yam production are caused by the specified agricultural inputs. The F-statistic value of 7,630 for the yam function is statistically significant at the $1 \%$ probability level, indicating the accuracy and appropriateness of the Cobb Douglas regression model. The outcome test result is significant with a $5 \%$ probability for the yam business. This indicates that the equation is not badly specified and that the hypothesis of logarithmic linearity between the variables of the model is correct.

The normality test for both equations is statistically significant at the $1 \%$ probability level, which justifies the use of the ordinary least squares estimation method for Cobb-Douglas models. The information criteria indicate the relevance of the specified explanatory variable presented in the models.

\section{Analysis of farm resource productivity in yam production in the study area}

From Table 1, empirical results have shown that planting material (SEDW) has a significant positive relationship with yam production. This implies that as the amount of planting material is increased, yam yield also increases. The result corroborates research findings reported by Izekor and Olumese (2010) and Aderinola and Akinrinola (2005) on yam production in southern Nigeria. In addition, manure (MAN), family work (FAL) and extension visit (EXT) have a stimulating influence on yam production. Similarly, an increase in these inputs (ie, MAN and FAL) would result in an increase in yam production. Usman et al. (2009) reported similar results for yam production in the Ogun area of Oyo State. On the other hand, the depreciation cost, which was an approximation of the use of capital, has a significant negative impact on yam production. This means that an increase in the depreciation cost of fixed assets used in yam production would result in a reduction in yam production. However, this 
is in line with the report of Izekor and Olumese (2010) on factors affecting farmers' production of yam seed production in south-eastern Nigeria.

The elasticity of yam production relative to planting material (0.412), family labour (0.081) and manure (0.229) is less than unity. This means that the average productivity of these inputs is greater than the marginal productivity. As such, the use of these inputs is at Stage II or at the rational stage of the conventional production area. As a result, these inputs are optimally used in yam production in the study area. The yam enterprise yield scale in Ebonyi State showed a declining return of 0.823 . This means that a continued increase in the use of specified inputs in yam production would result in a decrease in yam production in the long term. Average total factor productivity of approximately 5.795 \{(i.e. antilog $(1,757)\}$ was obtained from yam farms in the study area. This implies that the contribution of variable input productivity to total factor productivity in yam farms in the study area is high.

Table 1: Estimates of Cobb-Douglas production parameters for yam farmers in the study area

\begin{tabular}{|l|l|l|}
\hline Variable & Coefficient & t-value \\
\hline Constant & 1.821 & $(2.011)^{\star *}$ \\
\hline Planting material & 0.412 & $(6.059)^{* * *}$ \\
\hline Hired labour & -0.421 & $(-0.051)$ \\
\hline Family labour & 0.081 & $(2.520)^{* * *}$ \\
\hline Fertilizer & 0.085 & $(0.040)$ \\
\hline Manure & 0.229 & $(3.437)^{* * *}$ \\
\hline Land size & -0.009 & $(-1.286)$ \\
\hline Depreciation & -0.143 & $(-2.242)^{* *}$ \\
\hline Extension visit & .678 & $(3.040)^{* * *}$ \\
\hline $\mathrm{R}^{2}$ & 0.938 & \\
\hline Adjusted $\mathrm{R}^{2}$ & 0.834 & \\
\hline F-Statistic & & $7.630^{* * *}$ \\
\hline Akaike Criterion & -22.447 & \\
\hline Schwarz Criterion & -20.174 & \\
\hline Hannan-Quinn & -27.144 & \\
\hline Normality test & & $18.777^{\star * *}$ \\
\hline RESET test & & $4.07^{\star *}$ \\
\hline Return to scale & 0.823 & \\
\hline
\end{tabular}

Note: asterisks ${ }^{*}{ }^{* *}$, and ${ }^{* * *}$ represent significance levels at $10 \%, 5 \%$ and $1 \%$. Variables are as defined in equation (2)

Factors affecting multifactor productivity among yam farmers in the study area

The results revealed that the coefficients of farm size, hired labour, household size, and planting material were negative and significant at different probability levels. This means that a $10 \%$ increase in farm size, hired labour, household size, and planting material for yam producers will reduce the multifactor productivity to $5.6 \%, 1.05 \%, 2.2 \%$ and $0.45 \%$, respectively. Cultivation of large agricultural land would increase production costs, which could limit the acquisition of other production inputs. As a result, some agricultural inputs would be used irrationally which will result to decline in farm multifactor productivity. In addition, an increase in the number of man-days of paid labour would tend to limit the use of other agricultural inputs by an increase in variable costs. In addition, farmers with large numbers of households will likely allocate most of their financial resources to basic family needs, such as education and food consumption. This would further limit the use of other farm resources and have a negative impact on multifunctional productivity. Similarly, the increased use of planting material on limited or small farmland could result in unnecessary competition between stands, which could result in reduced production. The results corroborate the results of Okoye et al. (2007) on coconut farmers in Anambra State and Ukoha et al. (2010) on cassava growers in the state of Abia.

The coefficient for age, income from yam production, credits obtained and experience is positive and significant at the respective probability levels of $10 \%, 1 \%, 5 \%$ and $5 \%$. This means that a $1 \%$ increase in age, income, access to credit and experience will increase the multifactor productivity of yam farms by $0.071 \%, 0.133 \%, 0.543 \%$ and $0.139 \%$, respectively. The result presented expectations a priori and resembled the findings of Ukoha et al. (2010) regarding age, credit, income and experience, but was contrary to Gulunal (2008) findings; Okoye et al. (2007) and Materson (2005) for age. Increasing income from yam production and increasing access to credit would tend to facilitate the acquisition and efficient management of agricultural resources; and this has a positive implication on the farms' total factor productivity. On the basis of the magnitude of the marginal effect of the explanatory variables, the results revealed access to agricultural credit; household size and farmers' farming experience are major incentives available to regulate total factor productivity in yam producers in the study area.

Table 2: Cobb Douglas regression estimates of determinants of multifactor productivity among yam farmers in Ebonyi State, Nigeria

\begin{tabular}{|l|l|l|}
\hline Variable & Coefficient & t-value \\
\hline Constant & 4.453 & $(4.269)^{* * *}$ \\
\hline Farm size & -0.559 & $(-3.381)^{\star * *}$ \\
\hline Hired labour & -0.105 & $(-1.984)^{\star}$ \\
\hline Age & 0.071 & $(1.775)^{\star}$ \\
\hline Household size & -0.228 & $(-1.846)^{\star}$ \\
\hline Gender & -0.167 & $(-0.759)$ \\
\hline Education & 0.359 & $(0.878)$ \\
\hline Income & 0.133 & $(4.750)^{* * *}$ \\
\hline Extension visit & 0.059 & $(0.784)$ \\
\hline Credit & 0.543 & $(2.425)^{* *}$ \\
\hline Experience & 0.139 & $(1.981)^{* *}$ \\
\hline Fertilizer & 0.001 & $(0.097)$ \\
\hline Depreciation & -0.020 & $(-0.866)$ \\
\hline Planting material & -0.045 & $(-2.433)^{* *}$ \\
\hline $\mathrm{R}^{2}$ & 0.864 & \\
\hline Adjusted $\mathrm{R}^{2}$ & 0.394 & \\
\hline F-Statistic & $2.920^{* * *}$ & \\
\hline
\end{tabular}

Note: asterisks ${ }^{*}{ }^{* *}$, and ${ }^{* * *}$ represent significance levels at $10 \%, 5 \%$ and $1 \%$ respectively. Variables are as defined in equation (5), where $L^{*}$ represents the lead equation. 
The $\mathrm{R}^{2}$ values of 0.864 for yam farms, implies that about $86 \%$ of the changes in multifactor productivity in yam enterprises are explained by the explanatory variables specified in the model. The $\mathrm{F}$ ratios for yam companies are significant at $1 \%$, which implies that the data attest to the overall significance of the regression equation.

\section{Challenges facing yam farming in the study area}

Table 3 shows the challenges facing yam production in the study area. Inadequate finance was the major (44.17\%) challenge facing farmers in the area while inadequate transportation, bad roads and unavailability of enough hired labour accounted for $15.83 \%, 15.00 \%$ and $15.00 \%$, respectively. These constitute major factors affecting yam production in the study area.

Table 3: Distribution of the respondents according to challenges facing yam farming in the study area

\begin{tabular}{|l|l|l|}
\hline Constraints & Frequency & Percentage (\%) \\
\hline Inadequate land & 1 & 0.83 \\
\hline Inadequate finance & 53 & 44.17 \\
\hline $\begin{array}{l}\text { Unavailability of enough } \\
\text { hired labour }\end{array}$ & 18 & 15.00 \\
\hline Inadequate family labour & 4 & 3.3 \\
\hline Pest infestation & 1 & 0.83 \\
\hline Outbreak of yam disease & 0 & 0.0 \\
\hline Inadequate transportation & 19 & 15.83 \\
\hline Bad road & 18 & 15.00 \\
\hline $\begin{array}{l}\text { Inadequate marketing } \\
\text { system }\end{array}$ & 1 & 0.83 \\
\hline Low demand & 5 & 4.17 \\
\hline Total & 120 & 120 \\
\hline
\end{tabular}

Source: field survey, 2018

\section{Summary and recommendations}

The study analysed agricultural resource productivity and multifactor productivity among yam producers in Ebonyi State. Analysis of the productivity of agricultural resources revealed that all agricultural resources (with the exception of the depreciation cost based on the use of capital) were used rationally in the yam production enterprises. The multifactor productivity index was generated for each farm and the factors affecting it were determined using the ordinary least squares technique. Empirical results revealed that the significant factors affecting the multifactor productivity of yam producers were: farm size, hired labour, producer's age, household size, producer's income, access to credit, experience and amount of planting material.

The result obtained in the study shows that yam producers are mainly middle-aged men with an average age of 52 years. Insufficient funding, inadequate transportation, poor roads and lack of hired labour were the main challenges for farmers in the region. Therefore, the study advocates farm-level policies to intensify extension services for yam producers and credit facilities at a subsidized interest rate for yam producers in the state so as to maintain the current level of factor productivity.

In addition, a policy that should encourage the mechanization of yam production on farms is strongly recommended by the state as it will reduce the effects of high labour costs. Useful market information and greater availability of inputs for farmers will be very useful in enabling smallholders to increase their productivity and increase their incomes. The government should provide farmers with improved seeds at a very low cost or price to make them available to small farmers. Farmer education should be strongly advocated. This is important because the low education rate of farmers explains their inability to accept improved yam technologies. In addition, government policy should aim to attract and encourage agile youth to live in rural areas and to make agriculture a trade. Finally, it has been shown that the timeliness of farm operations has a positive impact on crop yields. For this reason, agricultural inputs should be made available in a timely manner. These inputs include: pesticides, herbicides, fertilizers, etc.

\section{REFERENCES}

1. Aderinola, E. A., \& Akinrinola, O. O. (2005). Profitability, input elasticity and return to scale for yam production in Ondo State, Nigeria. Proceedings of the 39th Conference of the Agricultural society of Nigeria. pp: 300-303.

2. Akinlo, A. E. (2006). Macroeconomics factors and total factor productivity in sub-Sahara African countries. International Research Journal of Finance and Economics, 1, 62-70.

3. Akpan, S. B., Aya, E. A., Essien, U. A., Akpan, O. D., \& Bassey, N. E. (2011). Analysis of total factor productivity among smallholder vegetable farmers in Akwa-Ibom State, Nigeria. Nigerian Journal of Agriculture, Food and Environment, 7(4), 68-74.

4. Amusa, N. A. (2000). Screening cassava and yam cultivars for resistance to anthreenose using toxic metabolic collectorichim species. Mycopalogologia, 150, 137-142.

5. Bamidele, F. S., Babatunde, R. O., \& Rasheed, A. (2008). Productivity analysis of cassava based production system in the guinea savannah: Case study of Kwara State Nigeria. American-Eurasian Journal of Scientific Research, 3(1), 33-39.

6. EBSMARD. (1996). Ebonyi state ministry of agriculture and rural development. Annual bulletin, Ebonyi state, Nigeria.

7. F.A.O. FAOSTAT database 2013. (Online). Retrieved from: http://bit.ly/nmqzZf.

8. Gulunal, F. (2008). Small is beautiful: Evidence of an inverse relationship between farm size and yield in Turkey. Working paper, No 551, the levy Economics institute P.O.B. 500 Amandale-on-Hudson, 2008; NY 12504-5000.

9. Ibitoye, S. J., \& Attah, E. S. (2012). An assessment of 
yam mini-sett utilization and profit level in Kogi State, Nigeria. International Journal of Applied Research and Technology, 1(5), 3-11.

10. Izekor, R. (2010). Root crops: Tropical development research handbook, pp. 18-20.

11. Izekor, S. I., \& Olumese, O. B. (2010). Determinants of yam production and profitability in Edo State, Nigeria. African Journal of General Agriculture, 6(4), 205-210.

12. Key, N., \& Mcbride, W. (2003). Production contracts and productivity in the US hog sector. American Journal of Agricultural Economics, 85(1), 121-133.

13. Kushwaha, S., \& Polycarp, M. (2001). Economics of scale yam production in Qua' am Pam L.G.A of Plateau State Nigeria. Proceedings of the $34^{\text {th }}$ Annual conference of Agricultural Society of Nigeria. Held at Abubakar Tafawa Belewa University, Bauchi, October 15-19-2001. pp 69-74.

14. Materson, T. (2005). Productivity, technical efficiency, and farm size in Paraguayan agriculture. The levy Economics Institute of Board College. 2005; Working paper No 490, Feb. 2007.

15. McCloskey, D. N. (1972). The enclosure of open fields: Preface to a study of its impact on the English efficiency of agriculture in the eighteenth century. Journal of Economic History, 32, 15-35.

16. Milana, C., Naseia, L., \& Zeli, A. (2008). Change in multifactor productivity in Italy from 1998 to 2004. Evidence from firm level data using DEA, EU Klens projects in the European Union: comparative industry approach, working paper, No.33.

17. Nigerian institute of social economic research (NISER). A characterization of industrial Demand for major agricultural commodities in Nigeria, Ajakaiye D. O. and Akando S. O. (Eds) Nigeria institute of social and economic research, Ibadan, Nigeria (2002)

18. NPC. (2006). National population commission. National population census figure; NPC Bulletin, 2006.

19. Okoye, B. C., Onyenweaku, C. E., \& Asumugha, G. N (2007). Economic efficiency of small holder's cocoyam farmers in Anambra state, Nigeria. A translog stochastic frontier cost function approach. Agricultural Journal, 2(4), 535-546.

20. Onyeabor, N., \& Alimba, J. O. (2006). Potentials of agrotourism for agricultural and research development, of 40th ASN in proceeding NRCRI, Umudike, Nigeria. pp. 228-231.

21. Pius, C. I., \& Odwrwuedemie, E. I. (2006). Determinants of yam production and economic efficiency among small-holder farmers in Southern Nigeria. Journal of Central European Agriculture, 7(2), 333-342.

22. Ukoha, O. O., Okoye, B. C., \& Emetu, J. (2010). Analysis of the determinants of total factors productivity among small-holder cassava farmers in Ohafia L.G.A. of Abia State. International Journal of Agriculture and Development. Retrieved from: https://mpra.ub.unimuenchen.de/26125/

23. Usman, M. K., Eyitayo, O. A., \& Anthony, T.O. (2009). Economics of seed yam production using minisett technique in Oyo state, Nigeria. Field Actions Science Reports, 4(10), 1-9.

\section{Funding sources}

This research did not receive any financial support from any funding agency. 


\section{Večfaktorska produktivnost manjših pridelovalcev sladkega krompirja na območju pokrajine Ebonyi v Nigeriji}

\section{IZVLEČEK}

V raziskavi so preučevali večfaktorsko produktivnost manjših kmetovalcev - pridelovalcev sladkega krompirja v južnih, severnih in osrednjih kmetijskih predelih države Ebonyi. Cilji raziskave so bili določiti družbeno-ekonomske značilnosti pridelovalcev sladkega krompirja na preučevanem območju, analizirati večfaktorsko produktivnost in obseg proizvodnje med malimi pridelovalci, določiti dejavnike, ki vplivajo na večfaktorsko produktivnost med majhnimi pridelovalci in določiti omejitve povečane proizvodnje sladkega krompirja na preučevanem območju. Za izbiro vzorca $120 \mathrm{kmetij}$ iz omenjenih treh kmetijskih predelov intenzivne pridelave sladkega krompirja je bila uporabljena dvostopenjska tehnika naključnega vzorčenja. CobbDouglassova proizvodna funkcija je bila uporabljena za analizo produktivnosti posameznih dejavnikov in obsega proizvodnje v enoti proizvodnje (kmetiji). Rezultati so pokazali, da bi koeficient velikosti kmetij, najete delovne sile, velikosti gospodinjstev in sadilnega materiala zmanjšal večfaktorsko produktivnost kmetij za 8,6 \%, 1,05 \%, 2,2 \% in 0,45 \%. Rezultati so tudi pokazali, da bi 10-odstotno povečanje starosti kmetov, dohodka, dostopa do kreditov in izkušenj povečalo večfaktorsko produktivnost kmetij za $0,071 \%, 0,133 \%, 0,543 \%$ in $0,139 \%$. Vrednost $\mathrm{R}^{2} 0,864$ pomeni, da približno $86 \%$ variabilnosti v večfaktorski produktivnosti na kmetijah razložijo pojasnjevalne spremenljivke v modelu. Ugotovljeni problemi vključujejo neustrezna zemljišča, slabe finančne pogoje, visoke stroške prevoza, najeto delovno silo, škodljivce in bolezni, slabo infrastrukturo, omrežje, neustrezna skladišča itd. Rezultati raziskave izražajo potrebo po aktivnih politikah za okrepitev svetovalnih služb, spodbujanje kmetijske mehanizacije in zagotavljanje kreditov po subvencionirani stopnji v državi.

Ključne besede: sladki krompir, Dioscorea spp., večfaktornost, produktivnost, mali pridelovalci, določniki, viri/sredstva 